Pacific Journal of Mathematics

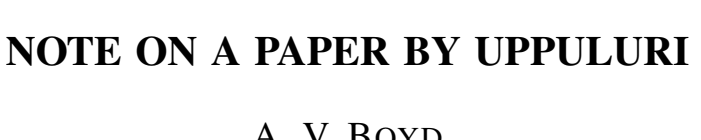




\section{NOTE ON A PAPER BY UPPULURI}

\section{A. V. BOYD}

By using the Battacharya bounds for the variance of an unbiased estimator V. R. Rao Uppuluri [1] claims to have established the result

$$
\frac{\Gamma(m+1)}{\Gamma\left(m+\frac{1}{2}\right)}>\left\{m+\frac{1}{4}+\frac{9}{48 m+32}\right\}^{\frac{1}{2}} \quad \text { for } m=1,2,3, \cdots,
$$

but a numerical calculation easily shows this to be incorrect, e.g. for $m=1$. In fact Watson [2] has shown, by using Gauss' theorem

$$
F(a, b ; c ; 1)=\frac{\Gamma(c) \Gamma(c-a-b)}{\Gamma(c-a) \Gamma(c-b)} \quad \text { for } c>a+b,
$$

that

$$
\begin{aligned}
\frac{\Gamma^{2}(x+1)}{x \Gamma^{2}\left(x+\frac{1}{2}\right)}= & \frac{\Gamma(x) \Gamma(x+1)}{\Gamma^{2}\left(x+\frac{1}{2}\right)} \\
= & F\left(-\frac{1}{2},-\frac{1}{2} ; x ; 1\right) \quad \text { for } x>-1 \\
= & 1+\frac{1}{4 x}+\frac{1}{32 x(x+1)} \\
& +\sum_{r=3}^{\infty} \frac{\left\{-\frac{1}{2} \cdot \frac{1}{2} \cdot \frac{3}{2} \cdots\left(r-\frac{3}{2}\right)\right\}^{2}}{r ! x(x+1) \cdots(x+r-1)} .
\end{aligned}
$$

It follows that

$$
\frac{\Gamma^{2}(x+1)}{\Gamma^{2}\left(x+\frac{1}{2}\right)}=x+\frac{1}{4}+\frac{1}{32 x+32}+O\left(x^{-2}\right) \text { as } x \rightarrow \infty,
$$

so that it is not possible to have

$$
\frac{\Gamma(m+1)}{\Gamma\left(m+\frac{1}{2}\right)}>\left\{m+\frac{1}{4}+\frac{1}{a m+b}\right\}^{\frac{1}{2}}
$$

for all positive integers $m$ if $a<32$.

It also follows that, for $m=1,2,3, \cdots$,

$$
\begin{aligned}
\left\{m+\frac{1}{4}+\frac{1}{32 m+32}\right\}^{\frac{1}{2}} & <\frac{\Gamma(m+1)}{\Gamma\left(m+\frac{1}{2}\right)} \\
& =\left(m+\frac{1}{2}\right) / \frac{\Gamma\left(m+\frac{3}{2}\right)}{\Gamma(m+1)} \\
& <\left\{\frac{\left(m+\frac{1}{2}\right)^{2}}{m+\frac{3}{4}+\frac{1}{32 m+48}}\right\}^{\frac{1}{2}} .
\end{aligned}
$$




\section{REFERENCES}

1. V. R. Rao Uppuluri, On a stronger version of Wallis' formula, Pacific J. Math. 19 (1966), 183-187.

2. G. N. Watson, A note on gamma functions, Proc. Edinburgh Math. Soc. 11 (1959), Notes, 7-9.

Received January 3, 1967.

UNIVERSITY OF THE WITWATERSRAND

SOUTH AFRICA 


\section{PACIFIC JOURNAL OF MATHEMATICS}

\section{EDITORS}

\section{H. SAMELSON}

Stanford University

Stanford, California

J. P. JANS

University of Washington

Seattle, Washington 98105
J. Dugundji

University of Southern California Los Angeles, California 90007

RICHARD ARENS

University of California

Los Angeles, California 90024

\section{ASSOCIATE EDITORS}
E. F. BECKENBACH
B. H. NeumanN
F. WOLF
K. YosidA

\section{SUPPORTING INSTITUTIONS}

UNIVERSITY OF BRITISH COLUMBIA

CALIFORNIA INSTITUTE OF TECHNOLOGY

UNIVERSITY OF CALIFORNIA

MONTANA STATE UNIVERSITY

UNIVERSITY OF NEVADA

NEW MEXICO STATE UNIVERSITY

OREGON STATE UNIVERSITY

UNIVERSITY OF OREGON

OSAKA UNIVERSITY

UNIVERSITY OF SOUTHERN CALIFORNIA
STANFORD UNIVERSITY

UNIVERSITY OF TOKYO

UNIVERSITY OF UTAH

WASHINGTON STATE UNIVERSITY

UNIVERSITY OF WASHINGTON

AMERICAN MATHEMATICAL SOCIETY CHEVRON RESEARCH CORPORATION TRW SYSTEMS

NAVAL ORDNANCE TEST STATION 


\section{Pacific Journal of Mathematics \\ Vol. 22, No. $1 \quad$ January, 1967}

Charles A. Akemann, Some mapping properties of the group algebras of a

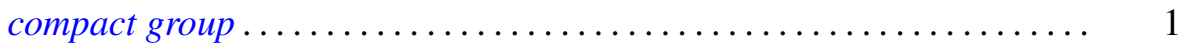

A. V. Boyd, Note on a paper by Uppuluri ..................... 9

Thomas Craig Brown, A semigroup union of disjoint locally finite subsemigroups which is not locally finite .....................

Richard Thomas Bumby and Everett C. Dade, Remark on a problem of

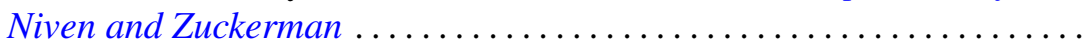

James Calvert, An integral inequality with applications to the Dirichlet problem .........................................

Jack Gary Ceder and Terrance Laverne Pearson, On products of maximally resolvable spaces ....................................

William Guignard Faris, The product formula for semigroups defined by

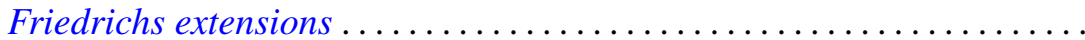

Robert S. Freeman, Closed operators and their adjoints associated with elliptic differential operators ........................ 71

Thomas Lee Hayden, The extension of bilinear functionals ............. 99

Gloria Conyers Hewitt, Limits in certain classes of abstract algebras . . . . . 109

Tilla Weinstein, The dilatation of some standard mappings ........... 117

Mitsuru Nakai, On Evans' kernel ......................... 125

Ernest Levane Roetman, On the biharmonic wave equation ............ 139

Malcolm Jay Sherman, Operators and inner functions ... . .

Walter Laws Smith, On the weak law of large numbers and the generalized elementary renewal theorem

A. J. Ward, On H-equivalence of uniformities: The Isbell-Smith problem 